\title{
Examination of Issues Encountered by Classroom Teachers in the Measurement and Assessment Process of the New Primary Education Curriculum in Turkey
}

\author{
Soner Mehmet ÖZDEMIR*
}

\begin{abstract}
This study aimed to establish the issues experienced by classroom teachers in the measurement and assessment process during the application of the new primary education curriculum in Turkey. For this purpose, a survey-based descriptive method was used in the research. The study was carried out with the participation of 287 senior level classroom teachers working in primary schools in the Kirıkkale provincial centre, Turkey. $55.1 \%$ of the teachers who participated in the study were male and $44.9 \%$ female. Data was gathered using a five item Likert scale developed by the researcher for the purpose of identifying the issues experienced by teachers during the measurement and assessment process. The results of the study indicated that classroom teachers experienced a high degree of issues in the measurement and assessment process relating to the six sub-factors of the scale, namely "alternative measurement- assessment tools", "time", "environment", "student", "parent" and "inspection elements". Furthermore, the study revealed that the teachers working in crowded classes ranging between 30-40 and 40-50 students faced a significantly higher level of issues compared to the teachers teaching class sizes ranging between 10-20 and 20-30 students. On the other hand, no significant difference was found between the views of the teachers regarding the issues they experienced during the measurement and assessment process according to gender and school they graduated from.
\end{abstract}

Keywords: Measurement and assessment process, primary school teachers, new primary education curriculum.

\footnotetext{
* Assist. Prof., Kirikkale University, Education Faculty, Department of Educational Sciences, Curriculum and Instruction, sonerozdem@yahoo.com
} 


\section{SUMMARY}

Purpose and significance: The purpose of this study was to investigate the issues experienced by classroom teachers during the measurement and assessment process and whether these issues differed according to the teachers' gender, schools they graduated from and the size of the class they currently teach. In Turkey, the new education curriculum based on constructivism was implemented in primary education as of the 2004-2005 school year. One of the most important aspects of the new curriculum is the measurement and assessment process. The effective use of the new measurement and assessment approaches by the teachers plays a significant role in achieving the objectives defined in the programs and in the students achieving effective learning. Therefore, teachers need to have the required knowledge and skill regarding the new measurement-assessment tools and approaches. A teacher lacking these abilities will experience difficulties in determining the students' learning achievement status and levels. In this respect, being aware of the issues experienced by the teachers during the measurement and assessment process and offering alternative solutions to address these issues is crucial. Since, in order to be able to evaluate their students more accurately and competently use these approaches the teachers need considerable knowledge, skill and experience

Methods: The present study was carried out using the descriptive method in the form of a survey model. This method was chosen because could identify the issues faced by classroom teachers during the measurement and assessment process in the application of the new primary education curriculum. The population of the study comprised of the primary schools in Kirıkkale provincial centre and the sample consisted of 287 classroom teachers from 21 schools selected from the population using the stratification method. $55.1 \%$ of the teachers in the study sample were male and $44.9 \%$ female. In terms of distribution of class size, $40.8 \%$ of the teachers who participated in the research had between 30-40 students in their class , whilst 38.7 \% had 20-30 students, $11.5 \%$ had $40-50$ and $9.1 \%$ had 10-20 students. The average class size may be considered quite crowded at 29.9 students. The data in the study was gathered using a Likert type scale for the purpose of identifying the issues experienced by classroom teachers during the measurement and assessment process developed by the researcher. As a result of the factor analysis carried out to test the validity of the structure, a 6-factor and 25-item structure emerged. The sub-factors of the scale were classified as "alternative measurement-assessment tools", "time", "environment", "student", "parent" and "inspection elements". As a result of the reliability analysis, the coefficient of consistence (Cronbach 
Alpha) was calculated and found to be quite high for all sub-factors of the scale and overall. The scale was designed in five-item Likert form and the choice intervals were defined as 1 (strongly disagree), 2 (disagree), 3 (undecided), 4 (agree) and 5 (strongly agree). For the analysis of the data, in addition to the frequency, percentage, arithmetic mean and standard deviation calculations; independent groups $t$ test and one-way analysis of variance (ANOVA) were carried out. The significance level was set as .05 for the differences between groups.

Results and Discussion: The results of the research showed that classroom teachers experienced a considerable level of difficulty in the measurement and assessment process during the application of the new primary education curriculums in relation to all dimensions of the scale. Teachers stated they experienced most difficulty relating to time, during the measurement- assessment process. Another significant result of the study was the fact that teachers working in with crowded classes (30-40 and 40-50 students) experienced more problems during the measurement and assessment process in relation to time, the teaching environment, alternative measurement- assessment tools and parents, compared to the teachers teaching classes with 10-20 and 20-30 students. On the other hand, it was found that the views of the teachers regarding the issues they faced during the measurement and assessment process did not vary significantly according to their gender and the school they graduated from. The recommendations presented as a result of this study include; comprehensive studies to be conducted in order to identify teachers' capability and the issues they encounter in relation to the measurement and assessment during the application process of new programs; hands-on training to be organised for teachers in subjects related to the new and alternative measurementassessment approaches and the ongoing evaluation of teachers in these subjects. 


\title{
Sınıf Öğretmenlerinin Yeni İlköğretim Programlarının Ölçme ve Değerlendirme Süreçlerinde Karşılaştıkları Sorunların İncelenmesi
}

\author{
Soner Mehmet ÖZDEMIR*
}

ÖZ: Bu çalışmanın amacı, sınıf öğretmenlerinin yeni ilköğretim programlarının uygulanmasında ölçme-değerlendirme süreçlerinde yaşadıkları sorunları belirlemektir. Bu amaçla, araştırmada tarama modeline dayalı betimsel yöntem kullanılmıştır. Araştırma, Kırıkkale il merkezindeki 21 ilköğretim okulunda görev yapan 287 birinci kademe sınıf öğretmeni üzerinde gerçekleştirilmiştir. Veriler, araştırmacı tarafından geliştirilen öğretmenlerin ölçme-değerlendirme sürecinde yaşadıkları sorunları belirlemeye yönelik beşli Likert tipi bir ölçekle elde edilmiştir. Çalışmanın sonuçları, sınıf öğretmenlerinin ölçme-değerlendirme sürecinde ölçeğin altı alt boyutu olan "alternatif ölçme-değerlendirme araçları", "zaman”, "ortam”, “öğrenci”, “veli” ve "denetim elemanları" ile ilgili oldukça yüksek düzeyde sorunlar yaşadıklarını göstermiştir. Çalışmada ayrıca, öğrenci sayısı 30-40 ve 40-50 arasındaki kalabalık sinıflarda görev yapan öğretmenlerin, öğrenci sayısı 10-20 ve 20-30 arasındaki sınıflarda görev yapan öğretmenlere göre yaşadıkları sorunlar anlamlı farklılık yaratacak ölçüde daha fazla bulunmuştur. Buna karşılık, öğretmenlerin ölçmedeğerlendirme süreçlerinde yaşadıkları sorunlara ilişkin görüşleri arasında cinsiyete ve mezun olunan okula göre herhangi bir anlamlı farklılık bulunmamıştır. Çalışma sonunda; öğretmenlerin yeni programların uygulanması sürecinde ölçme ve değerlendirme ile ilgili yeterliklerini ve karşılaştıkları sorunları belirlemeye ve bunları önlemeye yönelik kapsamlı çalışmaların yapılması önerilmiştir.

Anahtar sözcükler: Ölçme-değerlendirme süreci, sınıf öğretmenleri, yeni ilköğretim programları

* Yrd. Doç. Dr. Kırıkkale Üniversitesi, Eğitim Fakültesi, Eğitim Bilimleri Bölümü, Eğitim Programları ve Öğretim Anabilim Dalı, sonerozdem@yahoo.com 


\section{GíRIȘ}

Ölçme-değerlendirme, öğretim sürecinin ve bir eğitim programının ayrılmaz parçalarından biridir. Bir öğretmenin yapılan öğrenme-öğretme etkinlikleri sürecinde ya da süreç sonunda öğrencilerinin dersteki kazanımları veya ders konularını ne kadar öğrendiğini belirlemesi için belirli ölçme-değerlendirme araçları veya yöntemleri kullanmak durumundadır. Öğrenme-öğretme sürecinde öğretmenin bir dersi dikkatli ve sistemli biçimde planlaması ve uygulaması kadar, öğrencilerinin ne düzeyde öğrendiklerini belirlemeye yönelik etkili bir değerlendirme gerçekleştirmesi de önemlidir. Nitko'ya (2004) göre, eğitimde değerlendirme öğrenciler, eğitim programı ya da eğitim politikası hakkında kararlar vermek amaciyla kullanılan bilgilerin elde edilmesi sürecidir. Gronlund ve Linn (1990) ise değerlendirmeyi, öğretim hedeflerinin öğrenciler tarafından ne düzeyde kazanıldığının sistematik bir süreç olarak ele almıştır.

Ölçme ve değerlendirme etkinliklerinin öğretim sürecine pek çok katkısı vardır. Öğrencilerin öğretim sürecindeki bilişsel, duyuşsal ve psikomotor davranışlarındaki değişme ve gelişmeleri görmede, zamanında yapılan bir ölçme ve değerlendirme ile başarısız öğrencilerin öğrenme eksikliklerinin giderilmesinde, başarılı öğrencilerin güdülenmesinde ve aynı zamanda öğretmenlerin kendilerini değerlendirmelerinde ölçme ve değerlendirme önemli yer tutmaktadır (Semerci, 2007). Parkay'a (2006) göre, öğretim sürecinde değerlendirme yapma; 1. öğrencilerin öğretilen materyali ne düzeyde öğrendiklerini belirlemek, 2. öğrencilerin öğrenmesini sağlayan geri dönüt türlerini belirlemek, 3. öğretmenlerin etkililiğini geliştirmek için stratejiler geliştirmek ve 4 . öğrencilerin belirli performans düzeylerine ulaşıp ulaşmadıklarını belirlemek amaçlarına yöneliktir.

Bunun yanı sıra değerlendirme; "öğretimi geliştirmek ve öğrencilerin ihtiyaçlarını daha iyi biçimde karşılamak, öğrencilerin ailelerine ve topluma okul uygulamaları hakkında bilgi vermek, uygun bir eğitim programının planlanabilmesi için spesifik olarak öğrencilerin güçlü, zayıf yanlarını, sorunlarını ve ihtiyaçlarını belirlemek, arzulanan öğrenme çıtılarının ne düzeyde gerçekleştiğini görmek, öğrenmede meydana gelen ilerlemeleri belirtmek, öğrencilerin neleri yapabildiklerini ve başarabildiklerini rapor etmek" amaçlarına hizmet eder (Marsh ve Willis, 2007; Cohen, Manion ve Morrison, 1996). Öğrenme-öğretme süreçlerinde yapılan ölçme ve değerlendirme etkinlikleri, aslında öğrencilerin öğrenmesi ve öğretim süreciyle ilgili çeşitli kararların alınması amacıyla gerçekleştirilir. $\mathrm{Bu}$ kararlardan bazıları Nitko (2004) ve Worthen ve diğerlerine (1999; Akt. Doğanay ve Karip, 2006) göre şunlardır: 
"Sınıf öğretiminin yönetilmesi ile ilgili kararlar, öğrencilere notların verilmesi ile ilgili kararlar, öğretimle ilgili kararlar, öğrencilerin gelişim düzeyini, ilgilerini ve yeteneklerini teşhis etmeye yönelik kararlar, rehberlik ve danışmanlık ile ilgili kararlar, öğrenciler için eğitsel fırsatların, ortamların seçilmesi ile ilgili kararlar, öğretim programı ile ilgili kararlar ve öğrencilerin yeterliklerinin onaylanması ile ilgili kararlardır”. Bu kararlar, öğrencilerin eksikliklerinin belirlenerek bunlara uygun öğrenme yaşantılarının ve etkinliklerinin gerçekleştirilmesiyle öğrencilerin daha nitelikli öğrenmesine, öğretmenin kullandığı öğretim yöntemlerini ve öğretim anlayışını gözden geçirerek kendini geliştirmesine ve buna bağlı olarak da öğretim sürecinin daha nitelikli hale gelmesine katk1 sağlayabilecektir.

Günümüzde, öğrenci davranışlarını değerlendirme amacıyla kullanılan çoktan seçmeli, doğru-yanlış, eşleştirmeli, boşluk doldurmalı gibi klasik ölçme yöntemleri, öğrencilerde gözlemek istediğimiz okuduğunu anlama, yazılı anlatım, sunu yapma, araştırma-inceleme vb. becerileri ve özellikle de bunun daha üst biçimi olan yeteneği belirlemede yetersiz kalmaktadır (Kutlu, Doğan ve Karakaya, 2008). Son y1llarda, ülkemizde ilköğretim ve ortaöğretim sistemi gözden geçirilmeye başlanmış ve buna bağlı olarak da eğitim programlarında çeşitli değişiklikler gerçekleştirilmiştir. 2004 yılında başlayan bu çalışmalar sonucunda öncelikle ilköğretimin ilk kademesindeki öğretim programları yeniden geliştirilerek 2004-2005 öğretim yılında pilot uygulaması yapılmış, 2005-2006 yılından itibaren de uygulanmaya başlanmıştır. Yeni programlar yapılandırmacılık yaklaşımı temelinde geliştirilmiştir. Aşkar ve diğerlerine (2005) göre yapılandırmacı görüşten etkilenen ve bu yönde öğretim programları üzerinde çalışmalar yapan ve yapmış olan bazı ülkeler Avustralya, İngiltere, İrlanda, Amerika Birleşik Devletleri, Yeni Zelanda, İspanya, Finlandiya, İrlanda, İsrail, Avusturya, Kanada ve Singapur 'dur. Yapılandırmacılık yaklaşımına göre geliştirilen yeni öğretim programlarının önemli ögelerinden biri ölçme ve değerlendirmedir. Geliştirilen programlarda yapılan açıklamalarda, amaç, içerik ve öğrenme-öğretme süreçlerinde olduğu gibi, ölçme ve değerlendirme süreçlerinde de yeni bir anlayışın getirildiği vurgulanmaktadır. Yeni programlarda ölçme ve değerlendirme süreçlerindeki yeni anlayışs şu şekilde ifade edilmiştir (MEB, 2005):

“Bu programda, bireysel farklılıkları dikkate alan öğrenci merkezli öğretme ve ögrenme stratejileri benimsenmiştir. Bu nedenle ölçme ve değerlendirmede öğrencilerin bilgi, beceri ve tutumlarını sergilemeleri için çoklu değerlendirme kullanılmıştır. Sadece yazılı ve sözlü sınavlarla öğrenci başarısının ölçülmesi ve değerlendirilmesi uygun değildir. Çocukların yaşam becerilerini uygulama düzeyleri farklıdır. Bazı çocuklar eleştirel düşünmede ileri düzeydeyken, bazıları yaratıcılıkta, bazıları da kişisel gelişimlerini tanıma ve izlemede başarll olabilirler. Bu programda değerlendirme, ögrenme sürecine önem verir ve ögrencinin gelişimini izlemeyi amaçlar". 
$\mathrm{Bu}$ açıklamalara göre, yeni programlarda öğretmenin ölçme ve değerlendirme anlayışı da değişmektedir. Öğretmen, yalnızca öğrencilerin davranışlarına ya da ürüne bağlı olarak değerlendirme yapmak yerine, öğrencinin öğretim sürecinin başından sonuna kadar gösterdiği gelişim düzeyini, kendini ne kadar geliştirebildiğini, kişisel ve sosyal davranışları ne ölçüde kazandığını ve problem çözme, akıl yürütme, eleştirel, analitik, bilimsel, yaratıc1, sorgulayıc1 düşünme gibi becerileri ne düzeyde kazandığını belirlemeye yönelik bir yol izlemesini gerekmektedir. Klasik ölçme-değerlendirmede; daha çok hatırlamaya dayalı, tek doğru cevap üzerine temellendirilmiş, öğretim sürecinin sonunda yapılan, bilgilerin birbirinden bağımsız olarak ölçüldüğü, yazılı sınavlara dayalı olarak yapılan ve pek fazla geri bildirimin verilmediği bir anlayış varken, yapılandırmacı ölçme-değerlendirme sürecinde öğretmen ölçme ve değerlendirmeyi, öğrencilerin öğrenme süreçlerini ve neyi bildiklerini belirlemek ve sahip oldukları becerileri günlük yaşamda kullanabilmelerine katkıda bulunan bir araç olarak kullanmak durumundadır.

Bunun için, öğretmenlerin yeni programlarda belirtilen ölçme değerlendirme araçlarını özellikle alternatif değerlendirme araçlarını doğru ve etkili biçimde kullanmalarında yeterli bilgi, beceri ve deneyime sahip olmaları şarttır. $\mathrm{Bu}$ yeterliklerden ve deneyimden yoksun olan bir öğretmenin öğrencilerinin derslerdeki gerçek öğrenme durumlarını belirlemede sorunlar yaşaması ve başarısız olması da aşikârdır. Bu bakımdan, programları uygulama sürecinde oldukça bilgi, beceri ve deneyim gerektiren yeni ölçme-değerlendirme yaklaşımlarını kullanması gereken öğretmenlerin ölçme ve değerlendirme sürecinde yaşadıkları sorunların neler olduğunun bilinmesi ve buna göre gerekli önlemlerin alınması gerekmektedir. $\mathrm{Bu}$ çalışmada, ilköğretim kademesinin en önemli aktörlerinden biri olan sınıf öğretmenlerinin yeni ilköğretim programlarının uygulanması sürecinde öğrencilerin öğrenmelerini ölçme ve değerlendirmede yaşadıkları sorunları belirlemek ve buna ilişkin öneriler getirmek amaçlanmıştır. Bu genel amaç çerçevesinde bu çalışmada, öğretmenlerin ölçme ve değerlendirme sürecinde yaşadıkları sorunlar, öğretmenlerin cinsiyetine, kıdemine, mezun oldukları fakülteye, sinıf mevcuduna ve yeni ölçme-değerlendirme konularında hizmet içi eğitim alma durumlarına göre farklılık gösterip göstermediği de ortaya konmaya çalışılmıştır. 


\section{YÖNTEM}

\section{Araștırmanın Modeli}

$\mathrm{Bu}$ araştırmada, tarama modeline dayalı betimsel bir yöntem kullanılmıştır. Betimsel yöntem, bir evrendeki kişilerin görüşlerini, tutumlarını ve eğilimlerini evrendeki belli bir örneklem veya çalışma grubuyla çalışarak nicel veya sayısal olarak betimlemeyi amaçlar (Creswell, 2002). Buna göre, sınıf öğretmenlerinin yeni ilköğretim programlarının uygulanması esnasında ölçme-değerlendirme süreçlerinde yaşadıkları sorunları ortaya koymak amaçlandığından dolayı bu yöntem seçilmiştir.

\section{Evren ve örneklem}

Araştırmanın evrenini, Kırıkkale il merkezindeki 42 ilköğretim okulunda görev yapan 7451 . kademe sınıf öğretmeni, örneklemini ise bu okullardan tabakalama yöntemiyle seçilen 21 ilköğretim okulunda görev yapan 287 sınıf öğretmeni oluşturmuştur. Tabakalı (stratified) örnekleme yöntemi ile evrendeki alt grupların örneklemde temsil edilmelerinin garanti altına alındığı ve daha küçük örneklemlerle daha temsili istatistiklere ulaşılabildiği $(\mathrm{Balc1}, 2006)$ için bu örnekleme yöntemi seçilmiştir. Çalışmada örneklemde yer alan okulların seçiminde; okulların bulunduğu çevrenin sosyo-ekonomik düzeyleri, okulların merkeze uzaklıkları, okul ve sınıflardaki öğrenci sayıları ve farklı kıdem gruplarına sahip öğretmenler bakımından evreni en iyi yansıtacak dağılımda örneklemi seçmektir. Buna göre, çalışma kapsamında yer alan ögrretmenler; "farklı sosyo-ekonomik düzeydeki semtlerden, en merkezde bulunan ve merkeze uzak mesafede bulunan okullardan, öğrenci sayıları en fazla 20 olan sınıflar ile öğrenci sayıları 30-40, hatta 40-50 arasında değişen okullardan, mesleğe yeni başlamış 1-5 yıllık kıdeme sahip öğretmenlerin bulunduğu okullar ile meslekte deneyimli, 21 yıl ve üzeri öğretmenlerin görev yaptıkları okullardan" seçilmiştir. Örneklem kapsamında bulunan 315 öğretmenden, 287'si ölçme aracına gönüllü olarak cevap vermiştir ve bu sayı çalışma evreninde bulunan toplam öğretmen sayısının (745) üçte birinden daha fazlasını oluşturmaktadır. Payne ve McMorris'e (1967) göre, 750 kişilik bir evren için 254 kişilik örneklem yeterlidir. Buna göre, çalışma kapsamında seçilen örneklemin evreni temsil edecek sayıda olduğu söylenebilir. Çalışmaya katılan sınıf öğretmenlerinden \% 55,1'i (158) erkek, \% 44,9'u (129) ise kadındır. 


\section{Veri Toplama Aracı ve Geliştirilmesi}

Çalışmada veriler, sınıf öğretmenlerinin ölçme-değerlendirme sürecinde yaşadıkları sorunları belirlemek üzere geliştirilen bir ölçekle toplanmıştır. Ölçme aracının geliştirilmesinde öncelikle konuyla ilgili literatür ve yapılan araştırmalar incelenmiştir. Daha sonra, iki ilköğretim okulundan 12 sınıf öğretmeni ile görüşme yapılmış ve bu görüşme sonucunda öğretmenlerin ölçme ve değerlendirme konularında yaşadıkları sorunlar maddeler halinde listelenmiştir. Literatürden ve yapılan araştırmalardan elde edilen bilgi ve bulgular ile öğretmenlerle gerçekleştirilen görüşmelerden elde edilen nitel veriler doğrultusunda geniş bir madde havuzu oluşturulmuş ve bu madde havuzundan seçilen 31 madde ile bir ölçek taslağ hazırlanmıştır. Ölçekteki maddelerden birkaçı Acat ve Demir (2007a) tarafından yapılan çalışmanın ölçeğinden alınmıştır. Ölçek beşli likert şeklinde tasarlanmış ve seçenekler 1 (hiç katılmıyorum), 2 (katılmıyorum), 3 (kararsızım), 4 (katılıyorum) ve 5 (tamamen katılıyorum) aralıklarında düzenlenmiştir. Buna göre ölçekteki maddelerden alınabilecek en yüksek puan 5 ve en düşük puan da 1'dir. Geliştirilen taslak ölçek, geçerlik ve güvenirlik çalışması için 158 kişilik bir öğretmen grubuna uygulanmıştır. Bryman ve Cramer (2005) ön uygulama için yeterli temsil düzeyinin ölçekteki madde sayısının en az 5, en fazla 10 katı kadar kişiye ölçeğin uygulanması gerektiğini belirtmektedir. Bu çalışmada ön uygulaması yapılan ölçek toplam 31 maddeden oluştuğu için, 158 kişiye uygulanan ölçeğin (madde sayısının 5 katından daha fazla) yeterli temsil düzeyini yansıttığ̣ söylenebilir.

Ölçeğin yapı geçerliği için açımlayıcı faktör analizi yapılmıştır. Ölçeğin faktör yapısını belirlemek için temel bileşenler analizi ve varimax döndürme yöntemi uygulanmıştır. Ölçekteki verilerin faktör analizine uygun olup olmadığını ve örneklemin yeterliliğini belirlemek için KMO (Keiser-MeyerOlkin) ve Bartlett Testi yapılmıştır. Buna göre, KMO değeri .811 ve Bartlett testi 1733,892 $(\mathrm{p}<.000)$ çıkmıştır. KMO değerinin .90'larda olması mükemmel, .80'lerde olması çok iyi, .70'lerde ve .60'larda vasat ve .50 'lerde ve altında olması ise kötü olduğunu göstermekte ve Bartlett testi sonucunun manidar olması ise dağılımın normal olduğu anlamına gelmektedir (Tavşancıl, 2006). Buna göre, KMO değerinin .811 çıkması, bu veriler üzerine yapılan faktör analizinin oldukça güvenilir sonuçlar verdiğini ve Bartlett testi sonucunun anlamlı çıkması $(p<.000)$ ise bu verilerin faktör analizi yapmak için uygun olduğu anlamına geldiği söylenebilir.

Temel bileşenler analizi bulgularına göre, özdeğeri (eigenvalue) 1'in üzerinde olan ve varyansın \%70,019'unu açılayan 8 faktörün olduğu görülmüştür. Ayrıca, 8 faktör altında toplanan maddelerin bazıları yüksek faktör yüklerinde farklı faktörlerde yer almıştır. Bunlar 3., 7., 27. ve 31. 
maddelerdir. 3. madde .398 ile üçüncü faktöre ve .492 ile beșinci faktöre yüklenmiştir. 7. madde .412 ile altınc1 faktörde ve .500 ile yedinci faktörde, 27. madde .350 ile birinci faktörde, .389 ile altıncı faktörde ve 31 . madde ise .478 ile birinci faktörde ve .383 ile ikinci faktörde yer almaktadır. Bu maddelerin faktör yükleri iki farklı faktörde .100'den daha düşük oranda birbirine yakın faktör yüküne sahip olduğu ve binişiklik taşıdığı için ölçekten çıkarılarak tekrar faktör analizi yapılmıştır. İkinci analiz sonucunda ölçekteki faktörler bu kez 7 faktörde toplanmış ve açıklanan toplam varyans ise \%68,492 olarak hesaplanmıştır. İkinci rotasyon sonucunda 9. ve 15 . maddeler de yine .100 'den daha düşük düzeyde (9. madde altıncı faktörde .554 ve yedinci faktörde $.469,15$. madde beşinci faktörde .370 ve altınc1 faktörde .441) farklı faktörlere yüklendiği için ölçekten çıkarılmış ve kalan 25 madde aynı analizine tekrar tabi tutulmuştur. Yapılan son analizde maddeler varyansın \%66,965'ini açıklayan 6 faktörde toplanmış ve hiçbir madde birbirine en az .100'e yakın biçimde farklı bir faktörde yer almamıştır. Buna göre, faktör yükü .40'ın altında hiçbir madde yoktur, dolayısıyla ölçekte yer alan toplam 25 madde oldukça yüksek faktör yüküne sahiptir. Bu da ölçeğin yapı geçerliğinin oldukça yüksek olduğu ş̧eklinde yorumlanabilir. Ölçeğin alt faktörlerindeki maddeler incelendiğinde ilk faktörde yer alan 8 maddenin genel olarak alternatif ölçme-değerlendirme araçlarıyla ilgili olduğu, 2. alt faktördeki 4 maddenin zamanla ilgili olduğu, 3. alt faktördeki 3 maddenin öğretim ortamı ile ilgili olduğu, 4. alt faktördeki 3 maddenin öğrencilerle ilgili olduğu, 5. alt faktördeki 4 maddenin velilerle ilgili olduğu ve 6 . alt faktördeki 3 maddenin de denetim elemanları ile ilgili olduğu saptanmıştır. Buna göre, alt boyutlar şu şekilde adlandırılmıştır: 1. alt boyut "Alternatif ölçme-değerlendirme araçları ile ilgili sorunlar", 2. alt boyut "Zamanla ilgili sorunlar", 3. alt boyut "Ortamla ilgili sorunlar", 4. alt boyut "Öğrenci ile ilgili sorunlar", 5. alt boyut "Velilerle ilgili sorunlar" ve 6. alt boyut da "Denetim elemanları ile ilgili sorunlar".

Ölçeğe yönelik güvenirlik analizinde ise iç tutarlılık katsayısı Cronbach Alfa hesaplanmıştır. Buna göre, ölçeğin birinci alt boyutuna ait ölçümler için Cronbach Alfa katsayıs1 .87, ikinci alt boyut için .79, üçüncü alt boyuta yönelik.74, dördüncü alt boyut için .78, beşinci alt boyut için .76 ve altınc1 alt boyut için de .77 olarak bulunmuştur. Ölçeğin tümünden elde edilen ölçümler için Cronbach Alfa iç tutarlılık katsayısı ise .93 olarak hesaplanmıştır. Nunnally ve Bernstein'a (1994) göre güvenirlik için hesaplanan iç tutarlılık katsayısının en az .70 olması gerekir. Buna göre, ölçeğin ön uygulamasından elde edilen iç tutarlık katsayılarına göre ölçümlerin güvenirliğinin oldukça yüksek olduğu söylenebilir. Ölçekteki maddelerin faktör yükleri ve madde toplam korelâsyonları tablo 1'de verilmektedir. 
Tablo 1. Ölçekteki maddelerin faktör yükleri ve madde toplam korelasyonları

\begin{tabular}{|c|c|c|c|c|c|c|c|}
\hline Maddeler & 1. faktör & 2. faktör & 3. faktör & 4. faktör & 5. faktör & 6. faktör & $\begin{array}{c}\text { Mad- } \\
\text { Top.Kor. }\end{array}$ \\
\hline Madde 29 & .740 & & & & & & .6994 \\
\hline Madde 24 & .736 & & & & & & .7367 \\
\hline Madde 30 & .735 & & & & & & .6684 \\
\hline Madde 22 & .701 & & & & & & .6735 \\
\hline Madde 18 & .580 & & & & & & .7024 \\
\hline Madde 28 & .512 & & & & & & .6391 \\
\hline Madde 21 & .490 & & & & & & .5556 \\
\hline Madde 19 & .478 & & & & & & .4604 \\
\hline Madde 1 & & .819 & & & & & .7517 \\
\hline Madde 2 & & .807 & & & & & .7087 \\
\hline Madde 6 & & .519 & & & & & .5271 \\
\hline Madde 20 & & .354 & & & & & .4758 \\
\hline Madde 4 & & & .709 & & & & .5625 \\
\hline Madde 5 & & & .690 & & & & .5641 \\
\hline Madde 8 & & & .605 & & & & .5995 \\
\hline Madde 16 & & & & .842 & & & .7283 \\
\hline Madde 17 & & & & .805 & & & .6596 \\
\hline Madde 10 & & & & .502 & & & .4884 \\
\hline Madde 12 & & & & & .844 & & .5929 \\
\hline Madde 23 & & & & & .610 & & .5622 \\
\hline Madde 11 & & & & & .596 & & .5986 \\
\hline Madde 13 & & & & & .555 & & .5214 \\
\hline Madde 25 & & & & & & .699 & .6469 \\
\hline Madde 26 & & & & & & .570 & .5660 \\
\hline Madde14 & & & & & & .562 & .4770 \\
\hline
\end{tabular}

\section{Verilerin Çözümlenmesi}

Çalışmada elde edilen veriler SPSS programı kullanılarak analiz edilmiş ve analizlerde frekans, yüzde, aritmetik ortalama ve standart sapma değerleri alınmıştır. Ayrıca, araştırmaya katılan öğretmenlerin ölçeğin alt boyutlarına ilişkin verdikleri cevapların cinsiyete göre farklılaşıp farklılaşmadığına yönelik bağımsız gruplar $\mathrm{t}$ testi; öğretmenlerin sınıflarındaki öğrenci sayılarına ve mezun oldukları yüksek öğretim programına göre değişip değişmediğine yönelik ise tek yönlü varyans analizi (ANOVA) yapılmıştır. Gruplar arasında çıkan anlamlı farklılıklarda farkın hangi gruplar arasında 
olduğunu belirlemek için LSD testi yapılmıştır. Yapılan karşılaştırmalı analizlerde gruplara ait varyansların homojen olup olmadığını belirlemek için Levene testi bulgularına bakılmış ve yapılan t testi ve ANOVA analizlerinde grup varyanslarının birbirine eşit olduğu görülmüş̧ür. Gruplar arasındaki farklılıklarda anlamlılık düzeyi .05 olarak alınmıştır.

\section{BULGULAR}

$\mathrm{Bu}$ bölümde, sınıf öğretmenlerinin yeni ilköğretim programlarının uygulanması sürecinde ölçme-değerlendirme konularında yaşadıkları sorunlar ve bu sorunların cinsiyet, kıdem, mezun olunan üniversite, sınıftaki öğrenci sayısı ve ölçme-değerlendirme konusunda hizmet içi eğitim alma durumuna göre farklılaşıp farklılaşmadığına ilişkin karşılaştırmalı bulgular verilmiştir.

Öğretmenlerin ölçme-değerlendirme ile ilgili yaşadıkları sorunlara ilişkin bulgular

Tablo 2'de, araştırmaya katılan sınıf öğretmenlerinin ölçme değerlendirme sürecinde yaşadıkları sorunlara ilişkin görüşleri yer almaktadır. Tablodaki bulgulara göre, öğretmenlerin yeni ilköğretim programlarını uygulama sürecinde ölçme-değerlendirme konularında genel olarak oldukça yüksek düzeyde sorunlar yaşadıkları görülmektedir.

Tablo 2. Sınıf öğretmenlerinin ölçme-değerlendirme ile ilgili yaşadıkları sorunlar

\begin{tabular}{lccc}
\hline \multicolumn{1}{c}{ Boyutlar } & $\mathrm{N}$ & $\overline{\mathrm{X}}$ & $\mathrm{S}$ \\
\hline Alternatif ölçme-değerlendirme araçlarıyla ilgili sorunlar & 287 & 3,70 &, 65 \\
Zamanla ilgili sorunlar & 287 & 4,23 &, 59 \\
Ortamla ilgili sorunlar & 287 & 3,77 &, 77 \\
Öğrencilerle ilgili sorunlar & 287 & 3,80 &, 81 \\
Velilerle ilgili sorunlar & 287 & 3,76 &, 67 \\
Denetim elemanları ile ilgili sorunlar & 287 & 3,81 &, 74 \\
\hline
\end{tabular}

Tablodaki bulgular incelendiğinde, öğretmenlerin büyük bir kısmının öğrencilerin öğrenme durumlarını ölçme ve değerlendirmede en fazla zamanla ilgili sorunlar yaşadıkları dikkati çekmektedir. Öğretmenler "zaman" boyutuyla ilgili maddelere yönelik "tamamen katıliyorum" ( $\bar{X}=4,23$ ) düzeyinde görüş belirtmişlerdir. Zamanla ilgili sorunları içeren maddeler içinde öğretmenler en çok "Değerlendirme formlarını doldurmak 
çok zaman alıyor." $(\overline{\mathrm{X}}=4,54)$ ve "Değerlendirme formlarını doldurmak aşırı yük getirdiği için ders saatlerini etkili kullanamıyorum." $(\overline{\mathrm{X}}=4,53)$ maddeleri olmuştur. Bununla birlikte, çalışma kapsamında yer alan öğretmenler, diğer beş boyuttaki maddelerle ilgili de oldukça yüksek düzeyde sorunlar yaşadıklarını ifade etmişlerdir. Bu boyutlardaki maddelere yönelik öğretmenlerin görüşleri "katıllyorum" düzeyinde gerçekleşmiştir. Bu boyutlardaki sorunlar içinde öğretmenlerin en fazla sorun yaşadıkları maddelerden bazıları şunlardır:

- "Her ders ve etkinlik için performans değerlendirme ölçeklerini çoğaltmak ve uygulamak sorun yaratmaktadır." $(\overline{\mathrm{X}}=4,21)$,

- "Her ders ve ögrenci için ideal ölçme-değerlendirme yapmada ders dışı zaman yetersizliği yaşlyorum." ( $\overline{\mathrm{X}}=4,02)$

- "Ölçme-değerlendirme konularında teftişle ilgili objektif ve doğru normlar yok." $(\overline{\mathrm{X}}=4,00)$,

- "Müfettişler yeni programlardaki ölçme-değerlendirme konularında yeterince bilgi sahibi değiller." ( $\overline{\mathrm{X}}=3,98)$,

- "Velilerin eğitim düzeyleri ölçme-değerlendirme etkinliklerine yardımcı olmada yeterli değil." ( $\overline{\mathrm{X}}=3,94)$

- "Programdaki ve ders kitabındaki ölçme-değerlendirme etkinliklerini yapmak için sınıf mevcutları çok fazla." $(\overline{\mathrm{X}}=3,88)$.

Görüldüğü gibi, öğretmenlerin en fazla sıkıntı yaşadıkları konu, her ders ve etkinlik için performans değerlendirme ölçeklerini çoğaltmak ve uygulamanın yarattığı sorunlardır. Öğretmenler bunun yanında, velilerin ölçme-değerlendirme etkinliklerine yardımcı olmada eğitim düzeylerinin yeterince yüksek olmadığı, ölçme-değerlendirme konularında teftişle ilgili konularda objektif ve doğru normların olmadığı, kendilerini değerlendiren müfettişlerin de ölçme-değerlendirme konularında yeterince bilgi sahibi olmadıkları ve program ve ders kitaplarındaki ölçme-değerlendirme etkinliklerini yapmak için sınıflardaki öğrenci sayılarının çok fazla olduğu gibi temel sorunları vurgulamaktadırlar. 
Sinıf ögretmenlerinin ölçme-değerlendirme ile ilgili yaşadıkları sorunların cinsiyet değiskenine göre farklılĭgl

Tablo 3. Öğretmenlerin ölçme-değerlendirme ile ilgili yaşadıkları sorunların cinsiyete göre farklılığına ilişkin $t$ testi sonuçları

\begin{tabular}{|c|c|c|c|c|c|c|c|}
\hline Boyutlar & Cinsiyet & $\mathrm{N}$ & $\bar{X}$ & S & sd & $\mathrm{t}$ & $\mathrm{p}$ \\
\hline \multirow{2}{*}{$\begin{array}{l}\text { Alternatif ölçme-değerlendirme } \\
\text { araçlarıyla ilgili sorunlar }\end{array}$} & Kadın & 129 & 3,72 & ,66 & \multirow{2}{*}{285} & \multirow{2}{*}{, 527} & \multirow{2}{*}{, 599} \\
\hline & Erkek & 158 & 3,68 & 65 & & & \\
\hline \multirow{2}{*}{ Zamanla ilgili sorunlar } & Kadın & 129 & 4,24 & ,58 & \multirow{2}{*}{285} & \multirow{2}{*}{, 274} & \multirow{2}{*}{,785 } \\
\hline & Erkek & 158 & 4,22 & ,62 & & & \\
\hline \multirow{2}{*}{ Ortamla ilgili sorunlar } & Kadın & 129 & 3,74 & 84 & \multirow{2}{*}{285} & \multirow{2}{*}{,- 838} & \multirow{2}{*}{,403 } \\
\hline & Erkek & 158 & 3,82 &, 77 & & & \\
\hline \multirow{2}{*}{ Öğrencilerle ilgili sorunlar } & Kadın & 129 & 3,86 & 81 & \multirow{2}{*}{285} & \multirow{2}{*}{1,121} & \multirow{2}{*}{,263 } \\
\hline & Erkek & 158 & 3,75 &, 83 & & & \\
\hline \multirow{2}{*}{ Velilerle ilgili sorunlar } & Kadın & 129 & 3,70 & ,73 & \multirow{2}{*}{285} & - & \multirow{2}{*}{, 171} \\
\hline & Erkek & 158 & 3,81 & ,66 & & 1,374 & \\
\hline \multirow{2}{*}{$\begin{array}{l}\text { Denetim elemanları ile ilgili } \\
\text { sorunlar }\end{array}$} & Kadın & 129 & 3,80 & ,75 & \multirow{2}{*}{285} & \multirow{2}{*}{,- 315} & \multirow{2}{*}{,753 } \\
\hline & Erkek & 158 & 3,83 &, 72 & & & \\
\hline
\end{tabular}

Tablo 3'te öğretmenlerin ölçme-değerlendirme süreçlerinde yaşadıkları sorunlara ilişkin görüşlerinin cinsiyete göre farklılaşıp farklılaşmadığına yönelik $\mathrm{t}$ testi değerleri görülmektedir. Tablodaki bulgular, tüm boyutlarda öğretmenlerin ölçme-değerlendirme ile ilgili yaşadıkları sorunlara ilişkin görüşlerinin cinsiyete göre anlamlı düzeyde farklılaşmadığını göstermektedir. Buna göre, araştırma kapsamında yer alan hem kadın, hem de erkek öğretmenlerin ölçekteki ölçme-değerlendirme ile ilgili boyutlarda yer alan maddelere verdikleri cevapların birbirine oldukça benzerlik gösterdiği, bu bakımdan cinsiyet değişkenine göre anlamlı bir farklılığın oluşmadığı söylenebilir.

Sinıf öğretmenlerinin ölçme-değerlendirme ile ilgili yaşadıkları sorunların okuttukları sinıflardaki ögrenci sayısı bakımından farklılı̆̆ına ilişkin bulgular

Tablo 4'te görüldüğü gibi, ölçeğin "alternatif ölçme-değerlendirme araçları", "zaman", "öğretim ortamı" ve "veli” boyutlarında sinıf öğretmenlerinin sorunlara ilişkin görüşleri, okuttukları sınıflardaki öğrenci sayısına göre anlamlı düzeyde farklılık gösterirken, "öğrenci" ve "denetim elemanları" boyutlarındaki görüşler arasında ise anlamlı farkl1lık çıkmamıştır. "Alternatif ölçme-değerlendirme araçları" boyutunda, ortaya çıkan anlamlı farklılığın hangi gruplar arasında olduğunu belirlemek için yapilan LSD testinde, farklilıkların sinif mevcudu 10-20 ile 30-40, 20-30 ile 30-40 ve 20-30 ile 40-50 arasında olduğu saptanmıştır. Bir başka deyişle, okuttukları sınıfın mevcudu 30-40 ve 40-50 arasında olan öğretmenler, sınıf 
mevcutları 10-20 ve 20-30 arasında olan öğretmenlere göre alternatif ölçmedeğerlendirme araçlarına ilişkin daha çok sorun yaşadıklarını belirtmişlerdir.

"Zaman" boyutuna yönelik anlamlı farkl1l1klar incelendiğinde, LSD testine göre, anlamlı farklılıklar öğrenci sayıları 10-20 ile 20-30 arası, 10-20 ile 30-40 aras1 ve 10-20 ile 40-50 aras1 sinıflar1 okutan öğretmenlerin görüşleri arasında çıkmıştır. Bir başka anlatımla, okuttukları sınıflardaki öğrenci sayıs1 20-30, 30-40 ve 40-50 arasında olan öğretmenler, 10-20 arasında öğrencisi olan öğretmenlere göre zamanla ilgili daha fazla sorun yaşadıklarını ifade etmişlerdir.

Tablo 4. Öğretmenlerin ölçme-değerlendirme ile ilgili yaşadıkları sorunların okuttukları sınıflardaki öğrenci sayısı bakımından farklılı̆̆ına ilişkin $t$ testi sonuçları

\begin{tabular}{|c|c|c|c|c|c|c|c|c|}
\hline Boyutlar & $\begin{array}{c}\text { Öğrenci } \\
\text { say1s1 }\end{array}$ & $\mathrm{N}$ & $\bar{X}$ & $\mathrm{~S}$ & $\mathrm{sd}$ & $\mathrm{F}$ & $\mathrm{p}$ & $\begin{array}{c}\text { Fark } \\
\text { (LSD) }\end{array}$ \\
\hline \multirow{5}{*}{$\begin{array}{l}\text { Alternatif ölçme-değerlendirme } \\
\text { araçlarılla ilgili sorunlar }\end{array}$} & $10-20$ & 26 & 3,55 & ,66 & & \multirow{5}{*}{7,080} & \multirow{5}{*}{, 000} & \multirow{5}{*}{$\begin{array}{l}1-3 \\
2-3 \\
2-4\end{array}$} \\
\hline & $20-30$ & 111 & 3,51 & 63 & 3 & & & \\
\hline & $30-40$ & 117 & 3,87 & 65 & 283 & & & \\
\hline & $40-50$ & 33 & 3,84 &, 55 & 286 & & & \\
\hline & Toplam & 287 & 3,70 & 65 & & & & \\
\hline \multirow{5}{*}{ Zamanla ilgili sorunlar } & $10-20$ & 26 & 3,92 & ,76 & & \multirow{5}{*}{3,553} & \multirow{5}{*}{, 015} & \multirow{5}{*}{$\begin{array}{l}1-2 \\
1-3 \\
1-4\end{array}$} \\
\hline & $20-30$ & 111 & 4,19 & 62 & 3 & & & \\
\hline & $30-40$ & 117 & 4,31 &, 55 & 283 & & & \\
\hline & $40-50$ & 33 & 4,32 &, 48 & 286 & & & \\
\hline & Toplam & 287 & 4,23 &, 60 & & & & \\
\hline \multirow{5}{*}{ Ortamla ilgili sorunlar } & $10-20$ & 26 & 3,29 &, 88 & & \multirow{5}{*}{13,519} & \multirow{5}{*}{, 000} & $1-3$ \\
\hline & $20-30$ & 111 & 3,55 &, 79 & 3 & & & $1-4$ \\
\hline & $30-40$ & 117 & 3,94 &, 76 & 283 & & & $2-3$ \\
\hline & $40-50$ & 33 & 4,29 & 46 & 286 & & & $2-4$ \\
\hline & Toplam & 287 & 3,77 &, 80 & & & & $3-4$ \\
\hline \multirow{5}{*}{ Öğrencilerle ilgili sorunlar } & $10-20$ & 26 & 3,78 & ,84 & & \multirow{5}{*}{,665 } & \multirow{5}{*}{, 574} & \\
\hline & $20-30$ & 111 & 3,78 & 85 & 3 & & & \\
\hline & $30-40$ & 117 & 3,76 &, 84 & 283 & & & \\
\hline & $40-50$ & 33 & 3,98 & 62 & 286 & & & \\
\hline & Toplam & 287 & 3,80 &, 82 & & & & \\
\hline \multirow{5}{*}{ Velilerle ilgili sorunlar } & $10-20$ & 26 & 3,25 &, 73 & & \multirow{5}{*}{5,736} & \multirow{5}{*}{, 001} & \multirow{5}{*}{$\begin{array}{l}1-2 \\
1-3 \\
1-4\end{array}$} \\
\hline & $20-30$ & 111 & 3,80 &, 71 & 3 & & & \\
\hline & $30-40$ & 117 & 3,83 & ,62 & 283 & & & \\
\hline & $40-50$ & 33 & 3,87 & ,61 & 286 & & & \\
\hline & Toplam & 287 & 3,77 &, 68 & & & & \\
\hline \multirow{5}{*}{$\begin{array}{l}\text { Denetim elemanları ile ilgili } \\
\text { sorunlar }\end{array}$} & $10-20$ & 26 & 3,84 & ,79 & & \multirow{5}{*}{1,443} & \multirow{5}{*}{,230 } & \\
\hline & $20-30$ & 111 & 3,71 &, 80 & 3 & & & \\
\hline & $30-40$ & 117 & 3,91 & ,68 & 283 & & & \\
\hline & $40-50$ & 33 & 3,78 & 61 & 286 & & & \\
\hline & Toplam & 287 & 3,81 &, 73 & & & & \\
\hline
\end{tabular}


“Ortam” boyutuna ilişkin görüşler incelendiğinde, tabloda verilen LSD testi sonuçlarına göre, öğrenci sayıları 10-20 ile 30-40, 10-20 ile 40-50, 2030 ile $30-40,20-30$ ile $40-50$ ve 30-40 ile 40-50 arasinda olan sinifları okutan öğretmenlerin görüşleri arasında anlamlı farklılıkların çıktığı belirlenmiştir. Buna göre, öğrenci sayısı $30-40$ ve 40-50 arasındaki kalabalık sınıflarda görev yapan öğretmenler, $10-20$ ve 20-30 gibi daha az öğrencinin olduğu sınıflarda görev yapan öğretmenlere göre öğretim ortamı ile ilgili daha fazla sorun yaşadıklarını belirtmişlerdir. Ayrıca, öğrenci sayısı 40-50 arasında olan öğretmenlerin 30-40 arasında öğrenciye sahip öğretmenlere göre anlamlı fark çıkacak ölçüde daha fazla sorun yaşamaları da dikkat çeken bir başka husustur.

Anlamlı düzeyde farklılıkların bulunduğu bir diğer boyut da "veli" boyutudur. Bu boyuttaki farklılıklara ilişkin LSD sonuçlarına bakıldığında, anlamlı farklılıkların öğrenci sayıları 10-20 ile 20-30, 10-20 ile 30-40 ve 1020 ile 40-50 arasındaki sinıflarda görev yapan öğretmenler arasında olduğu saptanmıştır. Başka bir deyişle, sınıflarındaki öğrenci sayısı 20-30, 30-40 ve 40-50 arasında olan öğretmenler, öğrenci sayısı oldukça az olan 10-20 mevcuda sahip öğretmenlere göre velilerle ilgili daha fazla sorun algilamaktadırlar.

Bununla birlikte, "öğrenci” ve "denetim elemanları" boyutlarında ise öğretmenlerin sorunlara ilişkin görüşleri arasında anlamlı düzeylerde farklılık gerçekleşmemesine karşın, öğrenci boyutunda 40-50 arasında öğrenciye sahip öğretmenler, denetim elemanları boyutunda ise 30-40 arasında öğrencisi olan öğretmenler diğerlerine göre daha fazla sorun algıladıklarını belirtmişlerdir.

Sınıf öğretmenlerinin ölçme-değerlendirme ile ilgili yaşadıkları sorunların mezun olunan okula göre farklılığına ilişkin bulgular

Tablo 5. Öğretmenlerin ölçme-değerlendirme ile ilgili yaşadıkları sorunların mezun olunan okula göre farklılığına ilişkin ANOVA sonuçları

\begin{tabular}{llllllll}
\hline \multicolumn{1}{c}{ Boyutlar } & Mezun olunan okul & $\mathrm{N}$ & $\overline{\mathrm{X}}$ & $\mathrm{S}$ & $\mathrm{sd}$ & $\mathrm{F}$ & $\mathrm{p}$ \\
\hline $\begin{array}{l}\text { Alternatif ölçme- } \\
\text { değerlendirme araçlarıyla } \\
\text { ilgili sorunlar }\end{array}$ & $\begin{array}{l}\text { Eğitim fakültesi sınıf } \\
\text { öğretmenliği }\end{array}$ & 61 & 3,62 &, 74 & & 1,861 &, 101 \\
& Eğitim fakültesi & & & & & & \\
& (sin.öğrt.dış1) & 25 & 3,41 &, 65 & & & \\
& Eğitim enstitüsü & 67 & 3,77 &, 60 & 5 & & \\
& Eğitim yüksek okulu & 49 & 3,84 &, 57 & 281 & & \\
& AÖF lisans tamamlama & 37 & 3,74 &, 70 & 286 & & \\
& Diğger fakülteler & 48 & 3,68 &, 61 & & & \\
\hline
\end{tabular}




\begin{tabular}{|c|c|c|c|c|c|c|c|}
\hline & \multirow[b]{2}{*}{ Toplam } & \multirow[b]{2}{*}{287} & \multirow[b]{2}{*}{3,70} & \multirow[b]{2}{*}{, 65} & & \\
\hline & & & & & & & \\
\hline \multirow{7}{*}{ Zamanla ilgili sorunlar } & $\begin{array}{l}\text { Ĕgitim fakültesi sınıf } \\
\text { öğretmenliği }\end{array}$ & 61 & 4,13 & ,69 & & \multirow{7}{*}{1,027} & \multirow{7}{*}{,402 } \\
\hline & $\begin{array}{l}\text { Eğitim fakültesi } \\
\text { (sı.öğrt. dıș1) }\end{array}$ & 25 & 4,18 &, 59 & & & \\
\hline & Eğitim enstitüsü & 67 & 4,27 &, 55 & 5 & & \\
\hline & Eğitim yüksek okulu & 49 & 4,25 & 46 & 281 & & \\
\hline & AÖF lisans tamamlama & 37 & 4,16 &, 78 & 286 & & \\
\hline & Diğer fakülteler & 48 & 4,36 &, 51 & & & \\
\hline & Toplam & 287 & 4,23 & 60 & & & \\
\hline \multirow{7}{*}{ Ortamla ilgili sorunlar } & $\begin{array}{l}\text { Eğitim fakültesi sınıf } \\
\text { öğretmenliği }\end{array}$ & 61 & 3,56 & ,76 & & \multirow{7}{*}{1,585} & \multirow{7}{*}{, 164} \\
\hline & $\begin{array}{l}\text { Eğitim fakülttesi } \\
\text { (sın.öğrt.dış1) }\end{array}$ & 25 & 3,64 & ,92 & & & \\
\hline & Eğitim enstitüsü & 67 & 3,83 &, 87 & 5 & & \\
\hline & Eğitim yüksek okulu & 49 & 3,94 & 68 & 281 & & \\
\hline & AÖF lisans tamamlama & 37 & 3,78 & ,92 & 286 & & \\
\hline & Diğer fakülteler & 48 & 3,85 &, 70 & & & \\
\hline & Toplam & 287 & 3,77 &, 80 & & & \\
\hline \multirow{7}{*}{ Öğrencilerle ilgili sorunlar } & $\begin{array}{l}\text { Eğitim fakültesi sınıf } \\
\text { öğretmenliği }\end{array}$ & 61 & 3,86 &, 80 & & \multirow{7}{*}{,637 } & \multirow{7}{*}{,672 } \\
\hline & $\begin{array}{l}\text { Eğitim } \\
\text { fakülttesi(sın.öğrt.dışı) }\end{array}$ & 25 & 3,60 &, 85 & & & \\
\hline & Eğitim enstitüsü & 67 & 3,75 &, 80 & 5 & & \\
\hline & Eğitim yüksek okulu & 49 & 3,82 &, 87 & 281 & & \\
\hline & AÖF lisans tamamlama & 37 & 3,72 &, 88 & 286 & & \\
\hline & Diğer fakülteler & 48 & 3,90 & ,76 & & & \\
\hline & Toplam & 287 & 3,80 &, 82 & & & \\
\hline \multirow{7}{*}{ Velilerle ilgili sorunlar } & $\begin{array}{l}\text { Eğitim fakültesi sınıf } \\
\text { öğretmenliği }\end{array}$ & 61 & 3,63 & ,69 & & \multirow{7}{*}{,972 } & \multirow{7}{*}{,435 } \\
\hline & $\begin{array}{l}\text { Eğitim fakültesi } \\
\text { (sın.öğrt.dışı) }\end{array}$ & 25 & 3,66 & ,77 & & & \\
\hline & Eğitim enstitüsü & 67 & 3,83 & ,70 & 5 & & \\
\hline & Eğitim yüksek okulu & 49 & 3,82 &, 65 & 281 & & \\
\hline & AÖF lisans tamamlama & 37 & 3,85 & ,70 & 286 & & \\
\hline & Diğer fakülteler & 48 & 3,82 & ,63 & & & \\
\hline & Toplam & 287 & 3,76 & ,68 & & & \\
\hline \multirow{7}{*}{$\begin{array}{l}\text { Denetim elemanları ile } \\
\text { ilgili sorunlar }\end{array}$} & $\begin{array}{l}\text { Eğitim fakültesi sınıf } \\
\text { öğretmenliği }\end{array}$ & 61 & 3,62 &, 80 & & \multirow{7}{*}{1,647} & \multirow{7}{*}{, 148 } \\
\hline & $\begin{array}{l}\text { Eğitim fakültesi } \\
\text { (sın.öğrt.dıș1) }\end{array}$ & 25 & 3,66 &, 83 & & & \\
\hline & Eğitim enstitüsü & 67 & 3,88 & ,73 & 5 & & \\
\hline & Eğitim yüksek okulu & 49 & 3,97 &, 60 & 281 & & \\
\hline & AÖF lisans tamamlama & 37 & 3,86 &, 74 & 286 & & \\
\hline & Diğer fakülteler & 48 & 3,85 & 65 & & & \\
\hline & Toplam & 287 & 3,81 & ,73 & & & \\
\hline
\end{tabular}


Tablo 5'te, öğretmenlerin ölçme-değerlendirme ile ilgili yaşadıkları sorunların mezun olunan okula göre farklılı̆̆ına ilişkin ANOVA sonuçları verilmiştir. Tabloda görüldüğü gibi, ölçeğin 6 alt boyutunda da öğretmenlerin ölçme-değerlendirme konularında yaşadıkları sorunlara ilişkin görüşleri arasında mezun olunan okul bakımından anlamlı düzeyde farklılık çıkmamıştır. Buna karşılık, tablodaki aritmetik ortalamalara incelendiğinde, genel olarak sınıf öğretmenliğinden ve eğitim fakültesinden (sınıf öğretmenliği dışı) mezun olan öğretmenlerin yeni ölçme-değerlendirme uygulamaları sürecinde daha az sorun yaşadıkları, buna karşın, özellikle diğer fakültelerden mezun olanlar başta olmak üzere, eğitim yüksek okulu ve eğitim ön lisans-AÖF lisans tamamlama mezunu öğretmenlerin ise daha çok sorun algıladıkları dikkati çekmektedir.

\section{TARTISSMA, SONUÇ VE ÖNERILLER}

2004-2005 öğretim yılından itibaren uygulanmaya başlanan yeni ilköğretim programlarının etkili ve başarılı olmasının temel göstergelerinden biri, öğrencilerin nitelikli öğrenmeler elde etmeleri ve gerçek yaşam becerileri kazanmalarıdır. Bunun için, öğretmenlerin yeni programların en kritik ögelerinden biri olan ölçme ve değerlendirme konularında bilgi ve anlayış sahibi olmalarının yanı sıra, öğrencilerin farklı bilişsel, duyuşsal ve psiko-motor özelliklerini belirleyecek ölçme-değerlendirme araç ve etkinliklerini uygulayabilecek yeterliğe sahip olmaları gereklidir. Sınıf öğretmenlerinin yeni programların uygulanması sürecinde ölçmedeğerlendirme konularında yaşadıkları sorunların belirlenmeye çalışıldığı bu çalışmada, öğretmenlerin pek çok konuda önemli sorunlar yaşadıkları görülmüştür.

Çalışmanın sonuçları, öğretmenlerin ölçeğin alt boyutları olan "alternatif ölçme-değerlendirme araçları", "zaman", “ortam”, "öğrenci", "veli" ve "denetim elemanları" ile ilgili oldukça yüksek düzeyde sorunlar yaşadıklarını göstermiştir. Öğretmenlerin, bu boyutlar içinde en fazla sorun yaşadıkları konuların başında zaman yetersizliği gelmektedir. Öğretmenler gerek ölçme-değerlendirme etkinliklerini planlarken, gerekse de bunları uygularken ve değerlendirirken ders içi ve ders dışı zamanla ilgili önemli problemler yaşadıklarını belirtmişlerdir. Bununla birlikte, öğretmenlerin ölçme-değerlendirme etkinliklerinde en fazla sıkıntı yaşadıkları diğer konular ise, "değerlendirme formlarının çok olması ve aşırı yük getirmesi, denetim elemanlarının yeni ölçme-değerlendirme konularında yeterli bilgiye sahip olmamaları, velilerin eğitim düzeyinin yüksek olmaması ve sınıfların aşırı kalabalık olması"dır. Bu konuda yapılan çeşitli araştırmalarda elde 
edilen bulgular da bu bulguların birçoğunu destekler niteliktedir. Örneğin, Milli Eğitim Bakanlığının EARGED aracılığıyla 2005 yılında yaptığı yeni programları değerlendirme çalışmasında, sınıf öğretmenlerinin büyük bir kısmı Türkçe, hayat bilgisi, fen ve teknoloji, sosyal bilgiler ve matematik derslerini değerlendirirken ölçme-değerlendirme konularında önemli sorunlar yaşadıklarını belirtmişlerdir. Öğretmenlerin \%65 ile \%83'lük kısmı hem ölçme hem de değerlendirmenin çok karmaşık olduğunu, \%83 ile \%95 arasında değişen bir bölümü ise ölçme-değerlendirmenin çok zaman aldığını ifade etmiştir (EARGED, 2005).

Yine, Yaşar ve diğerleri (2005), Günay (2006), Acat ve Demir (2007a), Acat ve Demir (2007b), Çalık (2007), Yapıcı ve Demirdelen (2007), Tüfekçioğlu ve Turgut (2008) ve Ay, Karadağ ve Çengelci (2008) tarafindan yapılan çalışmalarda da sınıf öğretmenlerinin en çok; "zaman yetersizliği, sınıfların kalabalık olmasından dolayı değerlendirme faaliyetlerinin sağlıklı uygulanamaması, her ders ve etkinlik için performans değerlendirme ölçeklerini çoğaltmanın güç olması, formların karmaşık ve çok sayıda olması, öğrencilerin öz değerlendirme ve akran değerlendirmelerde objektif olmamaları, velilerin ölçme-değerlendirme süreçlerine müdahalesi, dersliklerin ve araç-gereçlerin yetersizliği, öğretmenlerin yeni ölçmedeğerlendirme yaklaşımları hakkında yeterince bilgilendirilmedikleri ve öğretmenlerin ölçme-değerlendirme tekniklerini uygulamada zorlanmaları" gibi sorunları yaşadıkları bulunmuş̧tur.

Çalışmada, öğretmenlerin ölçme-değerlendirme konularında yaşadıkları sorunlara ilişkin görüşlerinin cinsiyete göre farklılaşmadığı bulunmuştur. Bir başka ifadeyle, hem kadın hem de erkek öğretmenlerin ölçeğin alt boyutlarında belirtilen sorunlara ilişkin görüşleri birbirine oldukça benzerlik göstermektedir. Günay (2006) tarafından yapılan çalışmada ise, kadın öğretmenlerin erkek öğretmenlere göre yeni programların uygulanması ve değerlendirilmesi süreçlerinde yaşanan olumsuzluklara daha çok katıldıkları görülmüştür.

Araştırmada elde edilen sonuçlardan biri de, öğretmenlerin ölçmedeğerlendirme süreçlerinde karşılaştıkları sorunlara yönelik görüşlerinin sınıftaki öğrenci sayısına göre anlamlı düzeyde farklılaşmamasıdır. Sonuçlar, öğrenci sayısının fazla olduğu (30-40 ve 40-50 öğrenci) sınıflardaki öğretmenlerin özellikle "alternatif ölçme-değerlendirme araçları", "zaman", "öğretim ortamı" ve "veli"lerle ilgili konularda öğrenci sayısının az olduğu (10-20 ve 20-30 öğrenci) sinıflardaki öğretmenlere göre daha fazla sorun yaşadıklarını göstermiştir. Bir başka ifadeyle, 30-40 hatta 40-50 kişilik sinıflarda görev yapan öğretmenler, öğrencilerinin öğrenme durumlarını ölçme ve değerlendirmede özellikle zaman yetersizliği, değerlendirme 
formlarının aşırı yük getirmesi, sınıfların kalabalık olması ve ölçme değerlendirme araçları hakkında yeterince bilgi sahibi olamamaları gibi sorunları, öğrenci sayısının 10-20 ve 20-30 arasında olan öğretmenlere göre daha fazla yaşamaktadırlar. Bu sonuca göre, özellikle şehir merkezlerindeki okullarda sınıfların çoğunun kalabalık olmasından dolayı, öğretmenlerin ölçme-değerlendirme etkinliklerini istenilen nitelikte yerine getirmede ciddi sıkıntılar yaşadıkları söylenebilir.

Çalışmada ayrıca, öğretmenlerin görüşlerinin mezun oldukları yüksek öğretim programına göre farklılık göstermediği bulunmuş̧tur. Buna karş1lık, özellikle eğitim fakültesi dışındaki diğer fakültelerden, eğitim yüksek okulundan ve AÖF lisans tamamlama programından mezun olan öğretmenlerin, sınıf öğretmenliğinden ve eğitim fakültesinin çeşitli bölümlerinden mezun olan öğretmenlere göre ölçme-değerlendirme süreçlerinde daha çok sorun yaşadıkları görülmektedir. Bu sonuç, bu öğretmenlerin mezun oldukları yüksek öğretim programının bir öğretmen yetiştirme kurumu olmamasından dolayı, öğretmenlik formasyonundan yoksun oldukları ve bu nedenle de öğretmenlik mesleğine ve uygulamalarına ilişkin bilgi, beceri ve tutumlarının da genelde pek olumlu olmadığ anlamına gelebilir. Bu durumun ise sınıf öğretmenliğinden mezun olmayan öğretmenlerin ölçme ve değerlendirme süreçlerinde pek çok sorunla karşılaşmalarına ve bunları çözmede sıkıntılar yaşamalarına neden olduğu ileri sürülebilir.

Çalışmanın sonuçlarına dayalı olarak aşağıdaki öneriler sunulabilir: Öğretmenlerin yeni programların uygulanması sürecinde ölçme ve değerlendirme ile ilgili yeterliklerini ve karşılaştıkları sorunları belirlemeye yönelik olarak MEB ve il milli eğitim müdürlükleri kapsamlı çalışmalar yapmalıdır. Öğretmenlere yeni ve alternatif ölçme-değerlendirme yaklaşımları ile ilgili konularda özellikle akademisyenlerin katıldığ uygulamalı hizmet içi eğitim ve seminerler verilmelidir. Hizmet içi eğitim enstitülerinde ve illerde düzenlenen hizmet içi eğitim faaliyetlerinin ise adet yerini bulsun anlayışının dışına çıkılarak, öğretmenlerin aktif katılımının sağlandığı ve uygulamalı öğretim becerilerinin kazandırıldığı bir anlayışla düzenlenmesi gerekmektedir. Öğretmenlerin programlarda belirtilen ölçme ve değerlendirme etkinliklerini ne düzeyde gerçekleştirdiklerini belirlemek üzere sürekli değerlendirme ve rehberlik çalışmaları yapılmalıdır. Programların başarılı bir şekilde uygulanmasındaki en önemli ölçütlerden biri sınıflardaki öğrenci sayısının kalabalık olmamasıdır. Yeni programların gerektirdiği öğrenci merkezli etkinliklerin ve değerlendirme faaliyetlerinin etkin biçimde gerçekleştirilmesi için sınıf mevcutlarının 30'un olabildiğince altına çekilmesi gerekmektedir. 


\section{KAYNAKLAR}

Acat, M.B., \& Demir, E. (2007a). Sınıf öğretmenlerinin ilköğretim programlarındaki değerlendirme süreçlerine ilişkin görüşleri. 16. Eğitim Bilimleri Kongresi, 5-7 Eylül, Tokat: Gaziosmanpaşa Üniversitesi.

Acat, M.B., \& Demir, E. (2007b). İlköğretim programlarındaki alternatif değerlendirme yöntemlerinin uygulanmasında karşılaşılan sorunlara ilişkin sınıf öğretmenlerinin görüşleri. 1. Ulusal İlköğretim Kongresi, 15-17 Kasım, Ankara: Hacettepe Üniversitesi.

Aşkar, P., Paykoç, F., Korkut, F., Olkun, S., Yangın, B., \& Çakıroğlu, J. (2005). Yeni öğretim programlarını inceleme ve değerlendirme raporu. 30 Mayis 2005. http://www.erg.sabanciuniv.edu/

Ay, T.S., Karadağ, R., \& Çengelci, T. (2008). İlköğretim birinci basamakta gerçekleştirilen performans görevlerine ilişkin öğretmen görüşleri. VII. Ulusal Sınıf Öğretmenliği Eğitimi Sempozyumu, 2-4 Mayıs, Çanakkale: Çanakkale 18 Mart Üniversitesi.

Balcı, A. (2006). Sosyal bilimlerde araştırma. Yöntem, teknik ve ilkeler. (6. Baskı). Ankara: PegemA Yayıncılık.

Bryman, A., \& Cramer, D. (2005). Quantitative data analysis with SPSS 12 and 13: A guide for social scientists. London; New York: Routledge. Taylor \& Francis Group.

Cohen, L., Manion L., \& Morrison K. (1996). Teaching practice. London: Routledge.

Creswell, J.W. (2002). Research design. Qualitative, quantitative and mixed approaches. (2nd Ed). Thousand Oaks, California: Sage Publications.

Çalık, S. (2007). Sınıf öğretmenlerinin yenilenen ilköğretim programlarının ölçme ve değerlendirme süreci hakkındaki düşünceleri üzerine bir araştırma. 16. Eğitim Bilimleri Kongresi, 5-7 Eylül, Tokat: Gaziosmanpaşa Üniversitesi.

Doğanay, A., \& Karip, E. (2006). Eğitimde ölçme ve değerlendirme. İçinde, A. Doğanay ve E. Karip (Ed.). Öğretimde planlama ve değerlendirme. Ankara: PegemA Yayınc1lik.

EARGED. (2005). Temel ĕgitim destek programi. Öğretim programlarının (ilköğretim 1-5. sinuflar Türkçe, Matematik, Hayat Bilgisi, Fen Ve Teknoloji, Sosyal Bilgiler) değerlendirme raporu. Ankara: http://earged.meb.gov.tr/earged/subeler/olcme\%5Fdegerlendirme/doku manlar/ adresinden 18 Mart 2008 tarihinde erişilmiştir.

Gronlund, N. E., \& Linn, R. L. (1990). Measurement and assessment in teaching. (6th Ed.). New York, London: Macmillan Publishing Company.

Günay, Z. (2006). 2005-2006 öğretim yılında uygulamaya başlanan ilköğretim programlarına yönelik ögretmen görüşlerinin çeşitli 
değişkenler açısından karşılaştırmalı olarak incelenmesi. Yayımlanmamış yüksek lisans tezi, D.E.Ü. Eğitim Bilimleri Enstitüsü. İzmir.

Kutlu, Ö., Doğan, C. H., \& Karakaya, İ. (2008). Öğrenci başarısının belirlenmesi. Performansa ve portfolyoya dayall durum belirleme. Ankara: Pegem Akademi.

Marsh, C. J., \& Willis, G. (2007). Curriculum: Alternative approaches, ongoing issues (4th ed.). Upper Saddle River, NJ: Merrill Prentice Hall.

MEB. (2005). Illkögretim 1-5. sinıf programları tanitım el kitabı. MEB, TTK Başkanlığı, Eğitim Öğretim ve Program Dairesi Başkanlığı. Ankara: Devlet Kitapları Müdürlüğü Basımevi.

Nitko, A. J. (2004). Educational assessment of students. (4th Ed). Upper Saddle River, New Jersey: Pearson Prentice Hall.

Nunnally, J. C., \& Bernstein, I. H. (1994). Psychometric theory. New York: McGraw-Hill.

Parkay, F.W. (2006). Curriculum and instruction for becoming a teacher. Boston: Pearson Education and Allyn\&Bacon.

Payne, D.A., \& McMorris, R.F. (1967). Educational and psychological measurement. Waltham, Mass.: Blaisdell Pub.Co.

Semerci, Ç. (2007). Eğitimde ölçme ve değerlendirme. İçinde, E. Karip (Ed.). Ölçme ve değerlendirme. Ankara: PegemA Yayıncılık.

Tavşancıl, E. (2006). Tutumların ölçülmesi ve SPSS ile veri analizi. (3.Baski). Ankara: Nobel Yayın.

Tüfekçioğlu, N., \& Turgut, S. (2008). Yenilenen ilköğretim programı çerçevesinde değişen ölçme ve değerlendirme uygulamalarına sınıf ögretmenlerinin bakış açıları ve karşılaştıkları zorluklar. VII. Ulusal Sınıf Öğretmenliği Eğitimi Sempozyumu, 2-4 Mayıs, Çanakkale: Çanakkale 18 Mart Üniversitesi.

Yapıcı, M., \& Demirdelen, C. (2007). İlköğretim 4. sınıf sosyal bilgiler öğretim programına ilişkin öğretmen görüşleri. İlköğretim Online, 6(2). 204-212. [Online]: http://ilkogretim-online.org.tr adresinden 10 Mart 2008 tarihinde erişilmiştir.

Yaşar, Ş., Gültekin, M., Türkan, B., Yıldız, N., \& Girmen, P. (2005). Yeni ilköğretim programlarının uygulanmasına ilişkin sınıf öğretmenlerinin hazırbulunuşluk düzeylerinin ve eğitim gereksinimlerinin belirlenmesi (Eskişehir İli Örneği). Yeni İlköğretim Programlarının Değerlendirilmesi Sempozyumu, Eğitimde Yansımalar VII, 14-16 Kasım, Kayseri: Erciyes Üniversitesi. 